\title{
Egy háromdimenziós modellezó és grafikai program, a DAZ Studio alkalmazásának lehetôségei a testkép vizsgálatában
}

\author{
LEINDLER MILÁN ${ }^{1 *}$ - BENKÓ ZSÓFIA² - LAPIS FLÓRA² - \\ LÉDER ÁGOTA² - MOLNÁR KARINA² - SZALAI DOROTTYA ${ }^{2}$
}

${ }^{1}$ Semmelweis Egyetem. Magatartástudományi Intézet, Budapest ${ }^{2}$ Károli Gáspár Református Egyetem, Budapest

(Beérkezett: 2015. április 6.; elfogadva: 2015. július 24.)

\begin{abstract}
Elméleti háttér: Az evés- és testképzavarok vizsgálata egyre aktuálisabbá válik. A betegségcsoport spektruma a testképzavarok felé szélesedik, elófordulása pedig növekvố tendenciát mutat. A média egyre erősödő hatása hozzájárul a negatív testképhez és önértékeléshez, így a testkép vizsgálatának és korrekciójának jelentősége is növekszik. A testképvizsgáló eljárások nem tartanak lépést a fejlődő technológiával, így számos lehetôség marad kiaknázatlanul. Célkitüzés: A vizsgálat célkitúzése, hogy egy háromdimenziós modellezô és grafikai program, a DAZ Studio szoftver alkalmazási lehetóségét értékelje a testkép vizsgálatának területén. Célunk annak igazolása, hogy a program képes megmutatni a testkép attitúd-komponensét, az észlelt és az ideális test közötti eltérés mértékét és irányát. Módszerek: A DAZ Studio programban minden résztvevôvel két figurát készíttettünk el: elôször az észlelt, jelenlegi állapotát, másodszor pedig az ideális, vágyott állapotát. Emellett a szoftver validitásának igazolásához az Evési Zavar Kérdóív, az Eysenck-féle Személyiség Kérdôív, a Spielberger-féle Állapot- és Vonásszorongás Kérdôív, a Nagy Ötök Kérdốiv és a Fallon-Rozin-teszt kerültek felvételre. Ezen tesztek mérik a kitöltő általános önértékelését, szorongását és testéhez fúzôdố viszonyát. Eredmények: A vizsgálandó populáció a magyar nók voltak, a 73 fôs mintát kényelmi mintavétellel toboroztuk (átlagéletkor: 28,3 év, szórás: 10,8 év). Szignifikáns együttjárást találtunk a két figura közti különbség és az EDI releváns skálái között: a karcsúság iránti késztetéssel gyenge $(\mathrm{r}=0,272 ; \mathrm{p}=0,02)$, a testi elégedetlenséggel pedig közepesen erôs $(r=0,521 ; \mathrm{p}<0,001)$ korrelációt kaptunk. A 24 . életévüket még nem betöltöttek esetében ezek az értékek a következóképp alakultak: $\mathrm{r}=$ 0,454; $\mathrm{p}=0,003$ és $\mathrm{r}=0,639 ; \mathrm{p}<0,001$. Szignifikáns kapcsolatot találtunk továbbá a bulimiát mérő skála értékével $(r=0,390 ; p=0,013)$ és az elégtelenség érzésével is $(r=0,316 ; p=$ 0,047). A szorongással nem találtunk kapcsolatot. Következtetések: Megállapítható, hogy a DAZ Studio program alkalmas a testkép attitúd-komponensének vizsgálatára. Jelezni képes az észlelt és az ideális testkép közti eltérés mértékét és irányát, ami fontos diagnosztikai információt hordoz. Fiatalabb korúaknál az együttjárás még szorosabb, ezért a program alkalmas lehet a leginkább veszélyeztetett fiatalok körében az evés- és testképzavarok szúrésére.
\end{abstract}

Kulcsszavak: számítógép-alapú testképvizsgáló eljárások, evészavar, testképzavar, DAZ Studio, testképvizsgálat, anorexia

\footnotetext{
* Levelező szerző: Leindler Milán, 1192 Budapest, Zoltán utca 21. E-mail: leindlermilan@ gmail.com
} 


\section{Bevezetés}

\subsection{A testkép és vizsgálatának aktualitása}

Saját testünkról alkotott képünk képlékeny, folyamatosan formálódik a személyiségfejlődés és a szocializáció során (Tringer, 2010). A serdülókor végére alakul ki teljesen az önazonosság, mely magában hordozza a testkép megszilárdulását is. Évról évre azonban egyre több hatás befolyásolja identitásunkat és testképünket, ami elbizonytalanodáshoz vezethet. Elsôsorban az attitúd komponenst - saját testünkról alkotott vélekedésünket, értékítéletünket, gondolatainkat, ezzel kapcsolatos érzéseinket - éri a legtöbb negatív hatás a külvilág - akár a média, akár a család, barátok vagy kortársak - felól. E hatások képesek az énkép és az énideál közötti szakadékot elmélyíteni. Ez számos pszichiátriai betegség, mint az anorexia nervosa $(\mathrm{AN})$ vagy a bulimia nervosa $(\mathrm{BN})$ velejárója (Fredrickson \& Roberts, 1997), de elősegíti a szorongás és a depresszió kialakulását is. Megfigyelhetô, hogy az evés- és testképzavarok spektruma a testképzavarok felé tolódik (Szumska, Túry, \& Szabó, 2008), így a terápiás folyamatban egyre fontosabb a testkép korrekciója (Pászthy \& Major, 2008; Tölgyes \& Unoka, 2008). A testképról többkomponensú konstruktumként gondolkodunk, de az evési zavarokkal elsósorban a saját testtel kapcsolatos attitúdöket - az énkép és az ideális én közti szélsóséges eltérést - és nem a perceptuális komponenst hozták kapcsolatba (Keeton, Cash, \& Brown, 1990). Az evésés testképzavarok a pszichológiai kutatások egyik fókuszává váltak az elmúlt évtizedekben.

Sondhaus, Kurtz és Strube (2001) 1966 és 1996 között eltelt időszakban szignifikáns romlást jegyeztek fel a saját test megítélésében nók esetében, míg McElhone, Kearney, Giachetti, Zunft és Martínez (1999) vizsgálata szerint a nók mindössze 31\%-a elégedett saját testével. Tényként kezelhetố, hogy a serdülók és elsósorban a nók testképét egyre több negatív hatás éri (Bell, Lawton, \& Dittmar, 2007; Robles, 2009; Yuan, 2010), ami kedvezótlen hatással van a saját test elfogadására is (Turker, Bas, Saka, \& Metin, 2012). Harper és Tiggemann (2008) például kimutatta, hogy a médiában bemutatott idealizált, sovány testkép növeli az ausztrál nókben az elégedetlenség érzését a saját testtel kapcsolatban. Kiemelendô még, hogy generációkon átíveló jelenségról is beszélünk, hiszen egy anyákat és anorexiás lányaikat együttesen vizsgáló kutatásban (Izydorczyk, 2010) nagyon erős korrelációt találtak az anyák és lányaik kóros testképe között. Nem csupán az AN-ban szenvedók testképe érintett; Brytek-Matera és Schlitz (2011) eredményei alapján a bulimiások „ilyen szeretnék lenni” testképe torzultabb, mint az anorexiásoké. 
Az AN pontprevalenciája nyugat-európai országokban 0,9\% (Hoek \& van Hoeken, 2003), halálozási rátája felnôtteknél a megjelenés után 10 évvel 8\% (Túry \& Szabó, 2000). Steinhausen (2002) vizsgálatai alapján a túléló betegek esetében $47 \%$ a teljes gyógyulási arány, 33\% a kezelés mellett javulást mutat bizonyos tünetekben, de 20\% krónikusan anorexiás marad. González, Hernández és Marín (2012) rávilágít, hogy nagyobb veszélyben vannak azok, akiknél a betegség kialakulása korábbra tehetó - 19 éves koruk elóttre -, hiszen testképük szignifikánsan negatívabb. Ezen számok mellett még aggasztóbb, hogy Tasca és munkatársai (2012) eredményei szerint a restriktív AN-ban szenvedók mindösszesen 49\%-a, a BN-ban szenvedók pedig $70,5 \%$-a fogadta el a kezelést.

A testkép azonban nem csupán a klinikum területén játszik fontos szerepet; befolyásolja mindennapi közérzetünket, hangulatunkat, önértékelésünket is. Egy kutatás szerint az érzelmi labilitás erốsen korrelál a reálisideális testsúly különbségével (Swami, 2012), de legtöbbször az alacsony önértékeléssel és önbecsüléssel találnak szoros összefüggést (Delfabbro, Winefield, Anderson, Hammarström \& Winefield, 2011; Robles, 2009; Turker és mtsai, 2012). Mercurio és Rima (2011) egyetemistáknál azt tapasztalták, hogy a testtel való elégedetlenség és a testet monitorozó magatartásformák gyakorisága között pozitív korreláció áll fenn. Ez az objektifikációs elmélettel - mely szerint a testre, megjelenésre irányuló egyre nagyobb figyelem kedvez az ilyen irányú betegségek kialakulásának - „ördögi kört” alkot.

\subsection{Számítógépes testképvizsgáló eljárások}

A testkép vizsgálatára alkalmas számítógépes eljárásokat általánosságban már korábban bemutattuk (Leindler, 2014), itt csupán röviden foglaljuk öszsze óket. Az elmúlt három évtizedben számos méróeszköz látott napvilágot (1. táblázat), de csupán kevés került be a nemzetközi gyakorlatba. A módszerek egyik csoportja előre betáplált készlettel dolgozik és választást kínál a vizsgálati személyeknek (észak-amerikai irány), másik csoportja pedig a személy testét veszi alapul, és valós értékek mentén egy méretarányosan digitalizált figurával dolgozik (angol irány). Elóbbi inkább a testkép attitúd-komponensét, utóbbi inkább perceptuális komponensét vizsgálja.

Egyik kategóriában sem született olyan mérőeszköz, ami minden igényt kielégítene. A pszichológia ezen a területen sajnos nem tartott lépést a modern kor technológiai fejlódésével, így a megoldást a szakmán kívül kell keresnünk. Digitális fényképezógép és mérószalag helyett a test beolvasását ma már egyszerúen megoldhatjuk háromdimenziós (3D) szkennerek segítségével, melyek egyre szélesebb körben terjednek el és elérhetók hét- 
1. táblázat. Számítógépes testképvizsgáló eljárások

\begin{tabular}{|c|c|c|c|}
\hline & Eszköz & Szerzók & $\begin{array}{l}\text { Publikálás } \\
\text { éve }\end{array}$ \\
\hline \multirow{6}{*}{$\begin{array}{l}\text { Észak- } \\
\text { amerikai } \\
\text { irány }\end{array}$} & $\begin{array}{l}\text { Testkép Torzítottság Kiértékelése } \\
\text { (Body Image Distortion } \\
\text { Evaluation - BIDE) }\end{array}$ & Gustavson és mtsai & 1990 \\
\hline & $\begin{array}{l}\text { Testkép Teszteló Rendszer (Body } \\
\text { Image Testing System - BITS) }\end{array}$ & Schlundt \& Bell & 1993 \\
\hline & $\begin{array}{l}\text { Izomtömeg és Zsírszázalék } \\
\text { Mátrix (Somatomorphic Matrix) }\end{array}$ & $\begin{array}{l}\text { Gruber, Pope, } \\
\text { Borowiecki, \& Cohane }\end{array}$ & 2000 \\
\hline & $\begin{array}{l}\text { Serdülő Testképmódosító } \\
\text { Program (Adolescent Body } \\
\text { Morphing Tool - AdoBMT) }\end{array}$ & $\begin{array}{l}\text { Aleong, Duchesne \& } \\
\text { Paus }\end{array}$ & 2007 \\
\hline & $\begin{array}{l}\text { Testképzavar Számszerúsítése } \\
\text { (Quantification of Body Image } \\
\text { Disturbance - Q-BID) }\end{array}$ & Roy \& Forest & 2007 \\
\hline & $\begin{array}{l}\text { Testkép Összegzó Program } \\
\text { (Body Image Assessment } \\
\text { Software - BIAS) } \\
\end{array}$ & $\begin{array}{l}\text { Ferrer-García \& } \\
\text { Gutiérrez-Maldonado }\end{array}$ & 2008 \\
\hline \multirow{3}{*}{$\begin{array}{l}\text { Angol } \\
\text { irány }\end{array}$} & $\begin{array}{l}\text { Test-Forma Program } \\
\text { (Body-Shape Software) }\end{array}$ & $\begin{array}{l}\text { Benson, Emery, } \\
\text { Cohen-Tovée, \& Tovée }\end{array}$ & 1999 \\
\hline & $\begin{array}{l}\text { Anamorfikus Mikro } \\
\text { (Anamorphic Micro) }\end{array}$ & Shafran \& Fairburn & 2002 \\
\hline & TestKép (BodyImage) & Shibata & 2002 \\
\hline
\end{tabular}

köznapi felhasználók számára is. Az elôre betáplált készletekkel dolgozó eljárásokat pedig felválthatják a nem klinikai célra szánt grafikai programok - mint például a Digital Art Zone (DAZ) Studio -, melyek összehasonlíthatatlanul részletesebbek, élethúbbek és érzékenyebbek, mint a testképvizsgálatra szánt eddigi legfejlettebb szoftverek.

A Digital Art Zone Studio (a továbbiakban DAZ Studio) programban rejló lehetóségekról már korábbi, összefoglaló tanulmányunkban szót ejtettünk (Leindler, 2014). A szoftver első verziója 2005-ben jelent meg; azóta számos újítást, fejlesztést végeztek rajta. Az ingyenesen letölthetô DAZ Studio elsősorban grafikai programként szerepel a köztudatban, 3D-s modellezéshez használják illusztrátorok, divattervezók, grafikusok vagy múkedvelók. Kiválóan alkalmas élethú alakok megformálására; ruházatok, hátterek, kiegészító tárgyak, ékszerek, hajviseletek hatalmas tárháza érhetó el. Tetszólegesen állítható a figura testhelyzete, 360 fokban analóg módon, három tengely mentén forgatható, a test és az arc pedig holisztikus és csupán apró részletekre kiterjedó változók mentén is alakítható. 
A számítógépes módszerekkel szemben korábban megfogalmazott kritikák többsége - mint a módosítható testrészek alacsony száma, a részletgazdagság vagy az élethúség hiánya - a DAZ Studio program esetében nem érvényes, tehát mindenképpen előrelépésként tekinthetünk rá a számítógépes testképvizsgáló eljárások területén.

Az elsố és tudomásunk szerint az eddigi egyetlen kutatást a DAZ Studio programmal Crossley, Cornelissen és Tovée (2012) végezték. 4040 egészséges felnôtt férfi és nó testtömegindexét számolták ki, és a program - valamint a 3ds Max - segítségével ideális testképüket vizsgálták. A nók ideális testképének BMI értéke 18,9, a férfiaké 25,9 volt. Következtetésük szerint a legtöbb információt a felsótest hordozta. Az általuk használt verzió 94 állítható dimenziót tartalmazott, melyból a személyek átlagosan csupán 36-ot használtak. Ez fontos metodológiai eredmény, hiszen a jövóben feltétlenül érdemes vizsgálni, melyek a redundáns pontok. Bár a kutatás nem elsósorban a program használhatóságának vizsgálatát célozta, egyik legnagyobb érdeme, hogy egy nem klinikai használatra szánt szoftvert vont be a testkép - elsốsorban attitúd-komponensének - vizsgálatára.

\subsection{A jelen vizsgálat célja és hipotézisei}

A kutatás elsódleges célja, hogy igazoljuk, a DAZ Studio program alkalmas a testkép vizsgálatára. Feltételezzük, hogy az Evési Zavar Kérdóív (Eating Disorder Inventory - EDI) releváns skáláival - karcsúság iránti késztetés, testi elégedetlenség - szoros korrelációt mutat a DAZ Studio programmal kapott eredmény, mely az észlelt és a vágyott testkép közötti diszkrepanciát hivatott számszerúen mutatni. Továbbá feltételezzük, hogy a figurális ingereket alkalmazó Fallon-Rozin-tesztból nyert eredménnyel is korrelációt kapunk. Arra is számítunk, hogy a szorongás mértéke - STAI-T, EPQ-N skálák - is összefüggést mutatnak az ideális és az észlelt testkép különbségével.

\section{Módszer}

\subsection{Minta}

A vizsgálatban 73 nố vett részt. Tekintettel a kutatás exploratív jellegére, kényelmi mintavételt alkalmaztunk. A részvétel feltétele volt, hogy ne álljon pszichiátriai kezelés alatt a személy, ne szerepeljen kórelózményében bármilyen evés- és testképzavar, illetve látásában ne legyen korlátozott. A legfiatalabb résztvevő 18, a legidósebb 58 éves volt, az átlagéletkor 28,3, a 


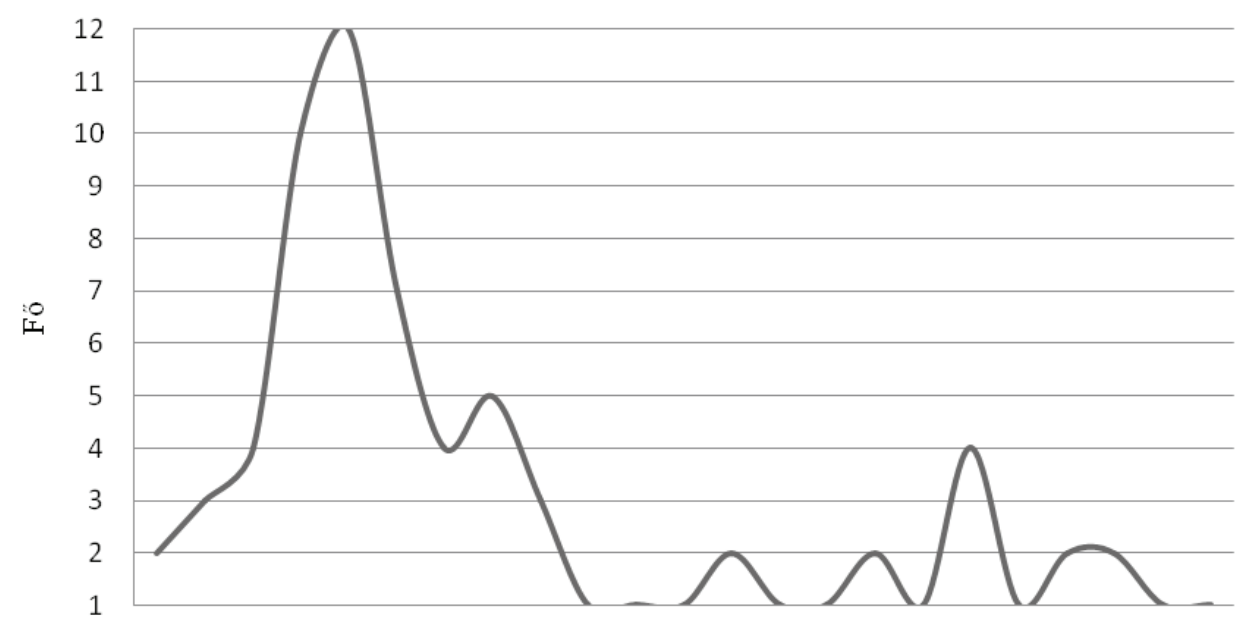

$\begin{array}{lllllllllllllllllllllll}18 & 19 & 20 & 21 & 22 & 23 & 24 & 25 & 26 & 28 & 30 & 31 & 34 & 41 & 42 & 43 & 46 & 47 & 48 & 49 & 50 & 54 & 58\end{array}$

Kor (év)

1. ábra. A minta életkor szerinti megoszlása

szórás 10,8 év volt. A megoszlás ebben a tekintetben egyenetlen, a vizsgálati személyek $71,2 \%$-a még nem töltötte be $27 ., 54,8 \%$-a pedig a 24 . életévét. Pontos életkori megoszlásuk az 1. ábrán látható. A 73 fót 10 érettségivel rendelkezó, 35 jelenlegi egyetemi hallgató és 28 felsőfokú végzettségú alkotta. Az etikai engedélyt az Egészségügyi Tudományos Tanács Tudományos és Kutatásetikai Bizottsága biztosította (14775/2013-EKU; 334/PI/12).

\subsection{Méróeszközök}

Fallon-Rozin-teszt (Emberalakrajzok Tesztje). Az Emberalakrajzok Tesztje (Fallon \& Rozin, 1985) az egyik legismertebb, figurális ingereket alkalmazó eljárás a testkép vizsgálatában. A teszt felvehetố nókkel és férfiakkal is, a személyeknek egy előre megrajzolt, egyre növekvő testsúlyú embereket ábrázoló 9-es sorozatból kell kiválasztani az instrukció szerinti figurát. Kérhetố a jelenlegi állapot, a vágyott állapot, a másik nem szerinti ideálisnak gondolt állapot, az általánosan ideális állapot, vagy a legkevésbé vágyott, legvisszataszítóbb állapot azonosítása is. A választások különbsége számszerúsíthetô, amiból levonhatók a megfelelő következtetések. Az 1985-ben publikált méróeszköz egyik hiányossága, hogy csupán a figurák testtömege változik, a test összetétele, izmossága nem.

Spielberger-féle Állapot-és Vonásszorongás Kérdôív (State-Trait Anxiety Inventory - STAI). A STAI Spielberger (1970) nevéhez fúzôdik. Magyarra 
való adaptációját elsősorban Sipos és Sipos (1983) munkájának köszönhetjük. Az önjellemzős teszt 40 kérdésból áll, melyból 20 vonatkozik az aktuális állapotra, 20 pedig a vonásjellegú szorongás mértékére. A kitöltőnek állításokat kell megítélnie egy 4-fokú skálán aszerint, hogy azok mennyire érvényesek rá. Ezek a fokozatok: soha, néha, gyakran és mindig. A teszten skálánként 20-80 pont érhetô el, a 20 extrém alacsony, a 80 extrém magas szorongást jelöl. Rövidsége, valamint jó validitása és megbízhatósága miatt esett a jelen kutatásban a választás a tesztre.

Nagy Ötök Kérdôív (Big Five Inventory - BFI). Az Allport munkásságán alapuló méróeszközt John és Srivastava (1999) publikálta. Öt személyiségvonást térképez fel: extraverzió, barátságosság, lelkiismeretesség, érzelmi stabilitás, nyitottság (Mirnics, 2006). A 44-tételes, önkitöltős teszt állításokkal való különböző mértékú egyetértés alapján mér ötfokú Likert-skálán.

Eysenck-féle Személyiség Kérdôív (Eysenck Personality Questionnaire EPQ). Az EPQ Eysenck biológiai szemléletú személyiségelméletén alapul, amely többek között a Galenus és Hippokratész által leírt típusokra épül (Eysenck \& Eysenck, 1975). A magyar adaptáció Eysenck és Matolcsi (1984) nevéhez fúződik. Két fő ellentétpárja az extroverzió-introverzió és a stabilitás-neuroticizmus, avagy labilitás. Az utóbbi skála magas értéke mellett a neurózisok kialakulási valószínúsége is nagyobb (Mirnics, 2006).

Evési Zavar Kérdôí (Eating Disorder Inventory - EDI). A Garner, Olmstead és Polivy (1983) által megalkotott EDI a legszélesebb körben elterjedt kérdốives módszer az evészavarok detektálására. Elônye elődeivel szemben, hogy a társuló pszichopatológiai jellegzetességeket is feltérképezi. A 64-tételes, Magyarországon jelenleg is használatos verziót Túry, Sáfrán, Wildmann és László (1997) adaptálták. Alskálái a karcsúság iránti késztetés, bulimia, testi elégedetlenség, elégtelenség érzése, perfekcionizmus, interperszonális bizalmatlanság, interoceptív tudatosság és a félelem a felnótté válástól. A tételeket Likert-skálán a "mindig”, "rendszerint", "gyakran”, „néha”, ,ritkán”, ,,soha” válaszok mentén pontozza a kitöltô.

A Cronbach-alfa-értékek minden skála esetében megfelelóek (0,6 felettiek); a kutatás fókuszában álló skálák (EDI / Karcsúság iránti késztetés, EDI / Testi elégedetlenség), valamint a STAI vonásszorongást és a BFI érzelmi instabilitást méró skálájának Cronbach-alfa-értéke 0,8 fölötti volt.

\subsection{Eljárás}

A kutatás során használt DAZ Studio 4.0 Pro alapesetben 45 manipulálható dimenziót kínál fel a használt modellhez, melyekból 11 univerzálisan, 34 pedig testrész-specifikusan módosítja az alakot. Ezekból elôzetesen ki- 


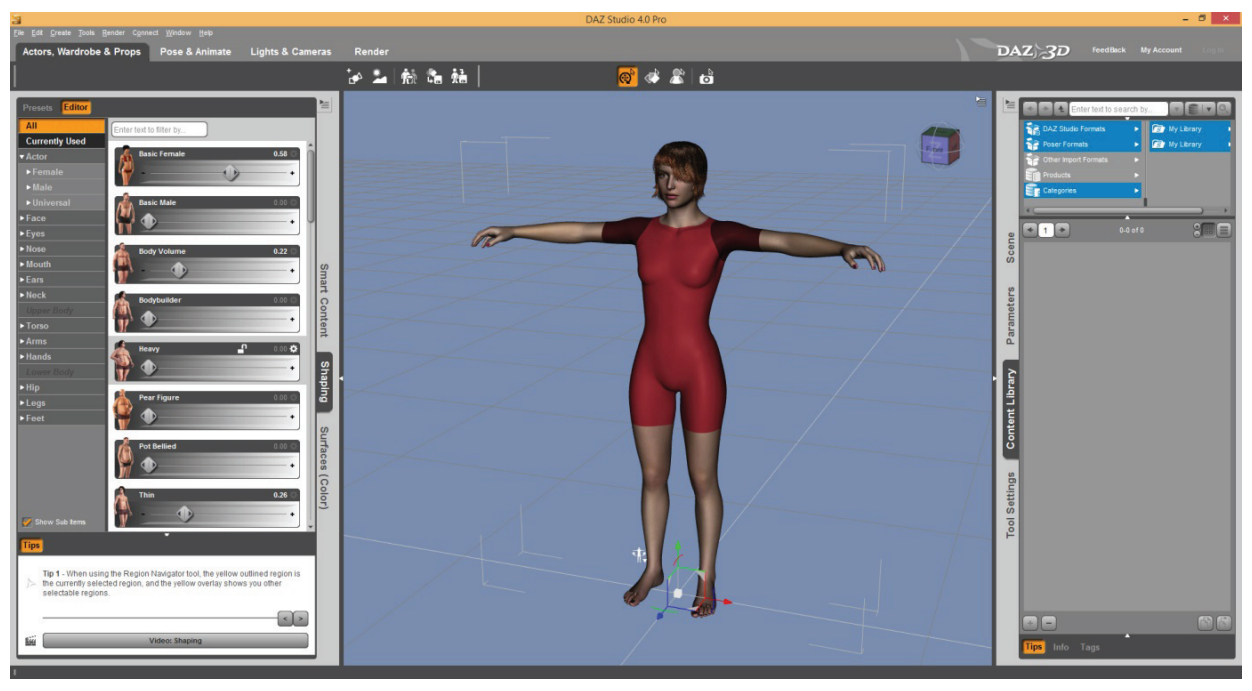

2. ábra. A DAZ Studio program kezelófelülete

vettük azokat, melyek a személy arcán található jellemzőit, vagy nagyon apró testrészeket módosítanak (pl. kézfej, térdkalács). Így a vizsgálatokhoz 22 dimenzió maradt a programban, melyek 0 - 1 között 1000 értéket vehetnek fel, de van olyan változó is, mint például a derékméret, ami -1 - 1 között értelmezhetô. A 22 alkalmazott dimenzió végül a nóiesség, testtömeg, nehézség, izmosság, sörhas, vékonyság, körtealak, férfiasság, nyakméret, derékméret, fenékméret, csípőcsont, vádliméret, combméret, vállméret, trapézméret, törzsméret, csípóméret, hátméret, felkarméret, alkarméret és a mellkasarány voltak. A Genesis modellt használtuk, melynek elônye, hogy unisex, tehát eredendóen nem rendelkezik nemi jellegekkel; azok külön beállíthatók. A modellhez testre simuló ruhát (Sample Lana Wetsuit) és hajat (Aldora Hair) is társítottunk (2. ábra).

A vizsgálati személyeknek elóször röviden ismertettük a program múködését. Bemutattuk a csúszkákat, a forgatási lehetóséget, valamint segítettünk, ha az angol nyelven szereplô megnevezések közül valamelyik nem volt érthetô. Az első instrukció a következô volt: „Alakítsa a program segítségével saját magát olyanra, amilyen jelenleg!" Idókeretet nem szabtunk a figura kialakítására. Ezután arra kértük a vizsgálati személyt, hogy alakítsa ki azt az alakot, ami ideális volna számára. A kiindulási alak esetében minden beállítás alapértéken (nullán) állt. Ez az átlagosnál vékonyabb kiindulási figurát eredményezett. Számolnunk kell a lehorgonyzási hatással, ez azonban kutatásunkban feltehetóen nem eredményezett torzítást, hiszen a kiindulás a két figura esetében azonos, s a két megalkotott figura különbségére fókuszáltunk. 
A figurák megalkotását és mentését követóen egy rövid kérdóívet töltöttek ki a vizsgálati személyek a programmal kapcsolatban (lásd Függelék). Kíváncsiak voltunk, hogyan értékelik a kezelhetôséget, milyen volt a szubjektív élményük a használat közben. Ezután kerültek sorra a papír-ceruza tesztek: az EDI, a STAI, az EPQ, a BFI és az Emberalakrajzok Tesztje. Az EPQ és a BFI esetében elsősorban a szorongás és az érzelmi labilitás skálákra fókuszáltunk.

\section{Eredmények}

A felvett tesztek leíró statisztikai eredményei a 2. táblázatban találhatók. Az Evési Zavar Kérdóív adaptációja során kapott adatokhoz képest a jelenlegi minta a karcsúság iránti késztetés dimenzióban szignifikánsan - 3,54 ponttal - magasabb átlagot mutat $(t=5,659 ; d f=72 ; p<0,001)$.

A tesztértékek korrelációi a 3. táblázatban találhatók. A szorongást és érzelmi labilitást mérő három skála szignifikánsan, közepes mértékben korrelál egymással. A STAI-T skála korrelációt mutat többek között az Evési Zavar Kérdôív karcsúság iránti késztetés skálájával, a testi elégedetlenség és az elégtelenség érzése skálákkal, az EPQ-N skála és a BFI-N (érzelmi stabilitás-labilitás) skála pedig a testi elégedetlenség, az interoceptív tu-

2. táblázat. A felvett tesztek (STAI, EPQ, BFI, EDI) leíró statisztikai eredményei

\begin{tabular}{|l|l|c|c|c|}
\hline $\mathrm{n}=73$ & \multicolumn{1}{|c|}{ Alskálák } & $\begin{array}{c}\text { Cronbach- } \\
\text { alfa }\end{array}$ & Átlag & Szórás \\
\hline STAI & Vonásszorongás & 0,867 & 46,27 & 8,595 \\
\hline \multirow{3}{*}{ EPQ } & Extroverzió & 0,854 & 11,97 & 4,952 \\
& Pszichoticitás & 0,722 & 3,07 & 4,012 \\
& Érzelmi instabilitás & 0,646 & 13,27 & 4,688 \\
& Szociális konformitás & 0,623 & 8,25 & 3,673 \\
\hline \multirow{5}{*}{ BFI } & Extraverzió & 0,770 & 27,01 & 5,245 \\
& Barátságosság & 0,689 & 32,22 & 6,378 \\
& Lelkiismeretesség & 0,827 & 30,18 & 6,983 \\
& Érzelmi instabilitás & 0,833 & 24,48 & 6,464 \\
& Nyitottság & 0,784 & 36,05 & 8,224 \\
\hline \multirow{5}{*}{ EDI } & Karcsúság iránti késztetés & 0,835 & 6,37 & 5,340 \\
& Bulimia & 0,764 & 1,67 & 2,186 \\
& Testi elégedetlenség & 0,846 & 8,04 & 5,673 \\
& Elégtelenség érzése & 0,639 & 3,36 & 3,736 \\
& Perfekcionizmus & 0,712 & 5,78 & 4,350 \\
& Interperszonális bizalmatlanság & 0,667 & 2,81 & 3,260 \\
& Interoceptív tudatosság & 0,757 & 2,84 & 3,492 \\
& Félelem a felnótté válástól & 0,808 & 5,03 & 4,422 \\
\hline
\end{tabular}


3. táblázat. A tesztértékek (STAI, EPQ, BFI, EDI) korrelációja

\begin{tabular}{|l|c|c|c|}
\hline $\mathrm{n}=73$ & STAI-T & EPQ-N & BFI-N \\
\hline STAI-T & - & 0,519 & 0,313 \\
& & $\mathrm{p}<0,001$ & $\mathrm{p}=0,007$ \\
\hline EPQ-N & 0,519 & - & 0,514 \\
& $\mathrm{p}<0,001$ & $\mathrm{p}<0,001$ \\
\hline BFI-N & 0,313 & 0,514 & - \\
\hline EDI - karcsúság iránti késztetés & $\mathrm{p}=0,007$ & $\mathrm{p}<0,001$ & \\
& 0,288 & 0,088 & 0,091 \\
\hline EDI - testi elégedetlenség & $\mathrm{p}=0,013$ & $\mathrm{p}=0,459$ & $\mathrm{p}=0,442$ \\
\hline EDI - elégtelenség érzése & 0,354 & 0,231 & 0,265 \\
& $\mathrm{p}=0,002$ & $\mathrm{p}=0,049$ & $\mathrm{p}=0,023$ \\
\hline EDI - interperszonális & 0,442 & 0,164 & 0,169 \\
bizalmatlanság & $0,0,001$ & $\mathrm{p}=0,165$ & $\mathrm{p}=0,152$ \\
\hline EDI - interoceptív tudatosság & 0,369 & 0,008 & 0,019 \\
& $\mathrm{p}<0,001$ & $\mathrm{p}=0,008$ & $\mathrm{p}=0,030$ \\
\hline EDI - félelem a felnótté válástól & 0,181 & 0,298 & 0,235 \\
& $\mathrm{p}=0,125$ & $\mathrm{p}=0,011$ & $\mathrm{p}=0,046$ \\
\hline
\end{tabular}

datosság és a félelem a felnótté válástól skálákkal. Ezek az értékek életkori bontások szerint csekély mértékben változnak, de minden esetben alacsonyak, kirívó esetben közepesek.

A 22 állítható DAZStudio dimenzió használatának megoszlása a két alak esetében a 3. ábrán láthatóak szerint alakult. Az elsó figuránál, mely a személyek észlelt, jelenlegi állapotát mutatja, mindegyik változót legalább a minta fele módosította. A legnépszerúbb dimenzió a nóiesség volt mindkét figura esetében, a legkevésbé népszerú pedig a férfiasság és a mellkas aránya. Nem volt kimutatható statisztikailag igazolható különbség az egészleges és a részletekre vonatkozó változók használatának gyakorisága között. Kiemelhetô, hogy három változó kivételével (nóiesség, vékonyság, izmosság) az összes dimenziót az elsó alak esetében módosították többen.

A feldolgozáshoz végül a fentebb bemutatott 22 dimenziót használtuk. Mindegyik változó esetében kiszámoltuk a két alak különbségét. Az így kapott 22 változó Cronbach-alfa értéke 0,589, de ha kiemeljük a testtömeghez nem szorosan köthetố vagy más egyéb szempont alapján ambivalens változókat (férfiasság, nóiesség, izmosság), akkor a Cronbach-alfa értéke 0,678 . Külön változóként kezeltük a különbségek összegét. Készítettünk egy súlyozott összeget is: a holisztikus dimenziókat felszoroztuk három- 


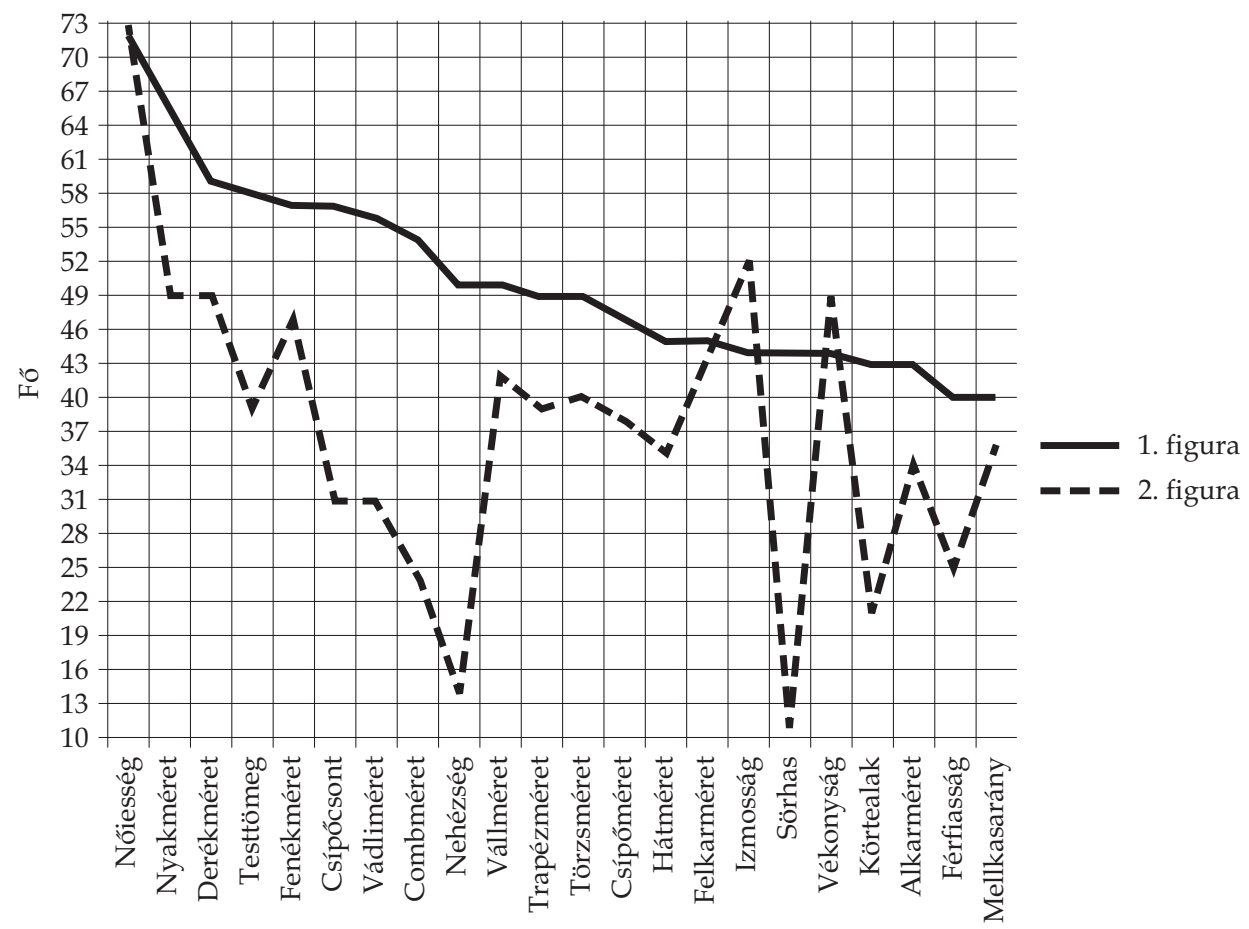

3. ábra. A 22 dimenzió és használatának megoszlása

mal, a nagyobb testrészekre kiterjedóket (derék, csípó, comb, mellkas) kettôvel, míg az apró részleteket módosító értékeket változatlanul hagytuk. Ennek célja az volt, hogy rendelkezésre álljon egy alternatív érték a számoláshoz, hiszen ugyanolyan skálán mozgó dimenziók különbözó méretú testrészeket manipulálnak. A súlyozással ezt a különbséget igyekeztünk kiegyenlíteni. A súlyozatlan összegek különbsége 63 esetben negatív, tehát a második figura karcsúbb, mint az elsố. A vágyott és az aktuálisan észlelt testkép diszkrepanciáját kifejezó mutató korrelál a Fallon-Rozin-teszt eredményeivel (vágyott alak és észlelt jelenlegi alak különbsége); a súlyozatlan különbség esetében a Spearman-féle korreláció $0,282(p=0,016)$ volt, míg a súlyozott különbség esetében $0,312(\mathrm{p}=0,007)$.

A 4. táblázatból kiolvasható, hogy az EDI karcsúság iránti késztetés és testi elégedetlenség skálájával a teljes minta és a korosztályos bontás után kapott részminták esetében is szignifikáns a korreláció a DAZ Studio programmal kapott értékekkel. Minél fiatalabb korosztályt vizsgálunk, a Pearson-korreláció értéke annál magasabb. A testi elégedetlenség skála pontszámaival különösen szoros együttjárás tapasztalható. Kiemelendó, hogy az EDI bulimia skáláján elért pontszámokkal is találtunk kapcsolatot, elsó- 
sorban a fiatalabbak körében, de az elégtelenség érzése is mutat szignifikáns együttjárást 24 év alattiak esetében. A többi teszt, illetve az EDI további négy skálája esetében nem találtunk szignifikáns korrelációt.

4. táblázat. Az észlelt és a vágyott alakok közti különbség és a többi tesztérték korrelációja

\begin{tabular}{|c|c|c|c|c|c|}
\hline & $\begin{array}{l}\text { Minta élet- } \\
\text { kor szerinti } \\
\text { bontása }\end{array}$ & $\begin{array}{l}\text { EDI - kar- } \\
\text { csúság irán- } \\
\text { ti késztetés }\end{array}$ & $\begin{array}{c}\text { EDI - } \\
\text { bulimia }\end{array}$ & $\begin{array}{l}\text { EDI - testi } \\
\text { elégedet- } \\
\text { lenség }\end{array}$ & $\begin{array}{l}\text { EDI - elég- } \\
\text { telenség } \\
\text { érzése }\end{array}$ \\
\hline \multirow{4}{*}{$\begin{array}{l}\text { Figurák } \\
\text { különbsége }\end{array}$} & $\begin{array}{l}\text { Teljes minta } \\
n=73\end{array}$ & $\begin{array}{c}0,272 \\
p=0,020\end{array}$ & $\begin{array}{c}0,167 \\
p=0,157\end{array}$ & $\begin{array}{c}0,521 \\
p<0,001\end{array}$ & $\begin{array}{c}0,012 \\
p=0,918\end{array}$ \\
\hline & $\begin{array}{c}35 \text { év } \\
\text { alattiak } \\
\mathrm{n}=57\end{array}$ & $\begin{array}{c}0,310 \\
p=0,019\end{array}$ & $\begin{array}{c}0,291 \\
p=0,028\end{array}$ & $\begin{array}{c}0,618 \\
p<0,001\end{array}$ & $\begin{array}{c}0,093 \\
p=0,491\end{array}$ \\
\hline & $\begin{array}{c}27 \text { év } \\
\text { alattiak } \\
\mathrm{n}=52\end{array}$ & $\begin{array}{c}0,338 \\
p=0,014\end{array}$ & $\begin{array}{c}0,266 \\
p=0,057\end{array}$ & $\begin{array}{c}0,618 \\
p<0,001\end{array}$ & $\begin{array}{c}0,189 \\
p=0,179\end{array}$ \\
\hline & $\begin{array}{c}24 \text { év } \\
\text { alattiak } \\
\mathrm{n}=40\end{array}$ & $\begin{array}{c}0,454 \\
p=0,003\end{array}$ & $\begin{array}{c}0,390 \\
p=0,013\end{array}$ & $\begin{array}{c}0,639 \\
p<0,001\end{array}$ & $\begin{array}{c}0,316 \\
p=0,047\end{array}$ \\
\hline \multirow{4}{*}{$\begin{array}{l}\text { Figurák súlyozott } \\
\text { különbsége }\end{array}$} & $\begin{array}{c}\text { Teljes minta } \\
\mathrm{n}=73\end{array}$ & $\begin{array}{c}0,254 \\
p=0,03\end{array}$ & $\begin{array}{c}0,202 \\
p=0,087\end{array}$ & $\begin{array}{c}0,499 \\
p<0,001\end{array}$ & $\begin{array}{c}0,010 \\
p=0,935\end{array}$ \\
\hline & $\begin{array}{c}35 \text { év } \\
\text { alattiak } \\
\mathrm{n}=57\end{array}$ & $\begin{array}{c}0,314 \\
p=0,018\end{array}$ & $\begin{array}{c}0,343 \\
p=0,009\end{array}$ & $\begin{array}{c}0,576 \\
p<0,001\end{array}$ & $\begin{array}{c}0,102 \\
p=0,451\end{array}$ \\
\hline & $\begin{array}{c}27 \text { év } \\
\text { alattiak } \\
\mathrm{n}=52\end{array}$ & $\begin{array}{c}0,323 \\
p=0,019\end{array}$ & $\begin{array}{c}0,319 \\
p=0,021\end{array}$ & $\begin{array}{c}0,566 \\
p<0,001\end{array}$ & $\begin{array}{c}0,181 \\
p=0,199\end{array}$ \\
\hline & $\begin{array}{c}24 \text { év } \\
\text { alattiak } \\
\mathrm{n}=40\end{array}$ & $\begin{array}{c}0,445 \\
p=0,004\end{array}$ & $\begin{array}{c}0,460 \\
p=0,003\end{array}$ & $\begin{array}{c}0,586 \\
p<0,001\end{array}$ & $\begin{array}{c}0,289 \\
p=0,070\end{array}$ \\
\hline
\end{tabular}

5. táblázat. A DAZ Studio programmal kapcsolatos elégedettségi kérdốiv értékei

\begin{tabular}{|l|c|c|}
\hline & Átlag & Szórás \\
\hline A program kezelhetósége & 3,45 & 0,925 \\
\hline A program külalakja & 3,96 & 0,808 \\
\hline A program használata által nyújtott élmény & 3,47 & 0,959 \\
\hline A program egyszerúsége & 3,58 & 1,096 \\
\hline A program által formázott figura valósághúsége & 3,66 & 0,963 \\
\hline A program által felkínált módositási lehetóségek mennyisége & 3,72 & 0,845 \\
\hline Az Ön általános elégedettsége a programmal kapcsolatban & 3,58 & 0,851 \\
\hline $\begin{array}{l}\text { Az Ön általános elégedettsége az elkészített alakokkal kapcsolat- } \\
\text { ban (milyen mértékben sikerült kialakítani azt, amit elképzelt) }\end{array}$ & 3,83 & 0,918 \\
\hline
\end{tabular}


A szoftver használatával kapcsolatos kérdơív eredményei az 5. táblázatban találhatók. Minden kérdés esetében az átlagértékek 3,4 és 4 között mozognak, szórásuk egy kivételével 1 alatt van. A 73 személyból csupán 64-gyel került felvételre a kérdốiv.

\section{Megbeszélés}

A DAZ Studio programmal kapott eredmények értelmezése elótt érdemes kitérnünk néhány általánosan levonható megállapításra, melyek nem kapcsolódnak szorosan a program használhatóságának vizsgálatához. Az Evési Zavar Kérdóív karcsúság iránti késztetés skáláján tapasztalt szignifikánsan magasabb pontszám igazolja az elmúlt évek jelenségét, miszerint nóknél a karcsúság iránti vágy egyre erősebb. Többek között ez lehet az egyik tényezố az AN egyre nagyobb arányú megjelenése mögött is. Ehhez kapcsolható az az észrevétel is, hogy összesen három olyan dimenzió volt a DAZ Studio programban, amit a vizsgálati személyek átlagosan több alkalommal használtak az ideális figura esetében, mint az észlelt állapotot mutató figura esetében: nóiesség (mely egyben enyhén karcsúsítja is a figurát), izmosság, vékonyság, valamint hogy a 73 résztvevóból 63 vékonyabb figurát formált másodszorra. Az Evési Zavar Kérdóív skálái és a többi teszt szorongást, érzelmi labilitást mérố skálái közti korreláció alátámasztja a már említett kutatási eredményeket, miszerint a saját testtel való elégedetlenség együtt jár az érzelmi instabilitással (Swami, 2012).

Az adatok szerint a DAZ Studio program alkalmas a testkép vizsgálatára. A szignifikáns korrelációk igazolják, hogy a szoftver hitelesen mutatja a testkép attitúd-komponensét, az ideális és az észlelt állapot közti különbség mértékét és annak irányát. Ez alátámasztható a Fallon-Rozin-teszttel kapott korrelációval is. Kiemelendó, hogy a program különösen erós együttjárást mutat a karcsúság iránti késztetéssel és a testi elégedetlenséggel a fiatalabb - és ezáltal az evés- és testképzavarok szempontjából veszélyeztetettebb - korosztályoknál. Fontos, hogy a 23 év alattiaknál nem csupán a saját testtel kapcsolatos skálákkal találtunk együttjárást, hanem az elégtelenség érzésével és a bulimia skálával is. Következésképpen a DAZ Studio egy rövid tesztfelvétel során információt nyújthat számunkra nem csupán a testi elégedetlenségról, hanem az általános önértékelésról is, esetenként pedig jelezhet fennálló patológiás állapotot is. Meg kell azonban jegyeznünk, hogy egyik korosztály esetében sem találtunk statisztikailag igazolható kapcsolatot a DAZ Studio értékei és a szorongás, érzelmi labilitás között. 
Összességében megállapítható, hogy érdemes a DAZ Studio-t és a hozzá hasonló programokat bevonni a klinikai vizsgálatok területére. Hatékony méróeszköz lehet, mely kiválóan helyt állhat egy olyan betegségcsoport felderítésében, melynek egyik fó jellemzôje, hogy az érintettek csekély százaléka jut csak el intenzív kezelésig (Tasca és mtsai, 2012). Kiváltképpen ajánljuk preventív jellegú felmérésekhez, hiszen nem kelti pszichológiai tesztelés képzetét a fiatalok számára könnyen kezelhetó, a bevonódást elósegító, játékos program használata. A továbbiakban javasoljuk AN-ban és BN-ban szenvedók mintáján is bemérni a programot, de hatékony lehet az izomdiszmorfia vagy a testépítő típusú evészavar (Túry \& Gyányi, 2007) kutatásában is. A szoftver viszonylag jól kezelhetônek és szimpatikusnak bizonyult a külön erre a célra szerkesztett kérdóív alapján. A 22 állítható dimenzió is elégségesnek bizonyult, nem volt olyan csúszka, amit ne használt volna legalább a résztvevốk fele az elsó figuránál, vagy legalább 10 fó a másodiknál. A 22 dimenziót skálaként is megvizsgáltuk, és nem találtunk olyan tételt, ami akár csak enyhén is kiemelkedett volna a többi közül, a 0,678-as Cronbach-alfa-érték elfogadhatónak mondható. A jövóben érdemes lehet több beépített modellel is kísérletezni, hiszen ezek különböző állítási lehetőségeket tartalmaznak és bizonyos módosításokra különbözóképpen reagálhatnak.

A súlyozott értékekkel való számolás nem hozott érdemben eltéró eredményt. Ez adódhat az alacsony elemszámból, a súlyozási rendszer kezdetlegességéból, de elképzelhetô, hogy szükségtelen a különbözố dimenziókat súlyokkal ellátni. Több vizsgált személy kiemelte, hogy nem tudja az alak magasságát, a láb hosszúságát állítani, és hiányoltak egy-egy részletes módosítási lehetôséget is, néhányan pedig a csúszkák érzéketlenségét kritizálták. A program értékelésére szánt kérdớivból érdemi többletinformációt nem nyertünk, a vizsgálati személyek általánosan jónak ítélték a szoftvert. Könnyứ kezelhetôsége, hozzáférhetôsége, részletgazdagsága és általános minôsége az eddig használt számítógépes testképvizsgáló eljárások fölé emeli a DAZ Studio programot, így reményeink szerint minél elóbb elterjed majd a klinikai gyakorlatban.

\section{Irodalom}

Aleong, R., Duchesne, S., \& Paus, T. (2007). Assessment of adolescent body perception: Development and characterization of a novel tool for morphing images of adolescent bodies. Behavior Research Methods, 39, 651-666.

Bell, B.T., Lawton, R., \& Dittmar, H. (2007). The impact of thin models in music videos on adolescent girls' body dissatisfaction. Body Image, 4, 137-145. 
Benson, P.J., Emery, J.L., Cohen-Tovée, E.M., \& Tovée, M.J. (1999). A computergraphic technique for the study of body size perception and body types. Behavior Research Methods, Instruments, \& Computers, 31, 446-454.

Brytek-Matera, A., \& Schiltz, L. (2011). Association between attitudes towards body image, negative emotions about one's own body and self-state representations in a clinical sample of eating disordered women. Archives of Psychiatry and Psychotherapy, 2, 37-43.

Crossley, K.L., Cornelissen, P.L., \& Tovée, M.J. (2012). What is an attractive body? Using an interactive $3 \mathrm{D}$ program to create the ideal body for you and your partner. PLOS ONE, $7,11$.

Delfabbro, P.H., Winefield, A.H., Anderson, S., Hammarström, A., \& Winefield, H. (2011). Body image and psychological well-being in adolescents: The relationship between gender and school type. Journal of Genetic Psychology, 172(1), 67-83.

Eysenck, H.J., \& Eysenck, S.B.G. (1975). Manual of the Eysenck Personality Questionnaire. San Diego, CA: Educational and Industrial Testing Service

Eysenck, S.B.G., \& Matolcsi, Á. (1984). Az Eysenck-féle Személyiség Kérdőív (EPQ) magyar változata: a magyar és az angol felnóttek összehasonlító vizsgálata. Pszichológia, 4, 231241.

Fallon, A.E., \& Rozin, P. (1985). Sex differences in perceptions of desirable body shape. Journal of Abnormal Psychology, 94(1), 102-105.

Ferrer-Garcia, M., \& Gutiérrez-Maldonado, J. (2008). Body Image Assessment Software: Psychometric data. Behavior Research Methods, 40, 394-407.

Fredrickson, B.L., \& Roberts, T. (1997). Objectification theory: Toward understanding women's lived experiences and mental health risks. Psychology of Women Quarterly, 21, 173-206.

Garner, D.M., Olmstead, M.P., \& Polivy, J. (1983). Development and validation of a multidimensional eating disorder inventory for anorexia nervosa and bulimia. International Journal of Eating Disorders, 2, 15-34.

González, M.Y.V., Hernández, S.O., \& Marín, J.I.L. (2012). Distortion of body perception in patients with early vs. late onset anorexia nervosa. Clinica y Salud, 23(2), 111-121.

Gruber, A.J., Pope, H.G., Borowiecki, J.J., \& Cohane, G. (2000). The development of the Somatomorphic Matrix: A biaxial instrument for measuring body image in men and women. In K. Norton, T. Olds, \& J. Dollman (Eds.), Kinanthropometry VI (217-231). Adelaide: International Society for the Advancement of Kinanthropometry

Gustavson, C.R., Gustavson, J.C., Pumariega, A.J., Reinarz, D.E., Dameron, R., Gustavson, A.R., et al. (1990). Body image distortion among male and female college and high school students, and eating-disordered patients. Perceptual and Motor Skills, 71, 1003-1010.

Harper, B., \& Tiggemann, M. (2008). The effect of thin ideal media images on women's self-objectification, mood, and body image. Sex Roles, 58, 649-657.

Hoek, H.W., \& van Hoeken, D. (2003). Review of the prevalence and incidence of eating disorders. International Journal of Eating Disorders, 34, 383-396.

Izydorczyk, B. (2010). Body image among young females with anorexia nervosa and the structure of body image among their mothers. Archives of Psychiatry and Psychotherapy, 4, 61-67.

John, O.P., \& Srivastava, S. (1999). The Big Five trait taxonomy: History, measurement, and theoretical perspectives. In L.A. Pervin, \& O.P. John (Eds.), Handbook of personality: Theory and research (2nd ed., 102-138). New York: Guilford 
Keeton, W.P., Cash, T.F., \& Brown, T.A. (1990). Body image or body images? Comparative, multidimensional assessment among college students. Journal of Personality Assessment, 54, 213-230.

Leindler, M. (2014). Számítógép-alapú testképvizsgáló eljárások. Mentálhigiéné és Pszichoszomatika, 15, 327-349.

McElhone, S., Kearney, J.M., Giachetti, I., Zunft, H.J., \& Martínez, J.A. (1999). Body image perception in relation to recent weight changes and strategies for weight loss in a nationally representative sample in the European Union. Public Health Nutrition, 2, 143-151.

Mercurio, A., \& Rima, B. (2011). Watching my weight: Self-weighting, body surveillance, and body dissatisfaction. Sex Roles, 65, 47-55.

Mirnics, Zs. (2006). A személyiség épitókövei. Budapest: Bölcsész Konzorcium

Pászthy, B., \& Major, M. (2008). Gyermek-és serdülókori evészavarok. In F. Túry, \& B. Pászthy (szerk.), Evészavarok és testképzavarok (25-40). Budapest: Pro Die

Robles, D.S. (2009). Thinness and beauty: When food becomes the enemy. International Journal of Research and Review, 2, 16-30.

Roy, M., \& Forest, F. (2007). Assessment of body image distortion in eating and weight disorders: The validation of a computer-based tool (QBID). Eating and Weight Disorders, 12, 1-11.

Schlundt, D.G., \& Bell, C.D. (1993). The Body Image Testing System: A microcomputer program for the assessment of body image. Journal of Behavioral Assessment and Psychopathology, 15, 267-285.

Shafran, R., \& Fairburn, C.G. (2002). A new ecologically valid method to assess body size estimation and body size dissatisfaction. International Journal of Eating Disorders, 32, 458-465.

Shibata, S. (2002). A Macintosh and Windows program for assessing body-image disturbance using adjustable image distortion. Behavior Research Methods, Instruments, $\mathcal{E}$ Computers, 34(1), 90-92.

Sipos, K., \& Sipos, M. (1983). The development and validation of the Hungarian form of the State-Trait Anxiety Inventory. Series in Clinical \& Community Psychology: Stress $\mathcal{E}$ Anxiety, 2, 27-39.

Sondhaus, E.L., Kurtz, R.M., \& Strube, M.J. (2001). Body attitude, gender and self-concept: A 30-year perspective. Journal of Psychology, 135, 413-429.

Spielberger, C.D., Gorsuch, R.L., \& Lushene, R.E. (1970). State-Trait Anxiety Inventory manual. Palo Alto, CA: Consulting Psychologists Press, Inc

Steinhausen, H.C. (2002). The outcome of anorexia nervosa in the 20th century. American Journal of Psychiatry, 159, 1284-1293.

Swami, V. (2012). Body image and personality: Associations between the Big Five Personality Factors, actual-ideal weight discrepancy, and body appreciation. Scandinavian Journal of Psychology, 54(2), 146-151.

Szumska, I., Túry, F., \& Szabó, P. (2008). Az evészavarok epidemiológiájának újabb adatai. In F. Túry, \& B. Pászthy (szerk.), Evészavarok és testképzavarok (109-120). Budapest: Pro Die

Tasca, G.A., Keating, L., Maxwell, H., Hares, S., Trinneer, A., Barber, A.M., et al. (2012). Predictors of treatment acceptance and of participation in a randomized controlled trial among women with anorexia nervosa. European Eating Disorders Review, 20, 155161. 
Tölgyes, T., \& Unoka, Zs. (2008). Az evészavarok kognitív megközelítése: sémák és személyiség. In F. Túry, \& B. Pászthy (szerk.), Evészavarok és testképzavarok (223-235). Budapest: Pro Die

Tringer, L. (2010). A pszichiátria tankönyve. Budapest: Semmelweis Kiadó

Turker, P., Bas, M., Saka, M., \& Metin, S. (2012). Body image dissatisfaction and risk factors among female adolescents: A sample from Turkey. HealthMED, 6, 3307-3315.

Túry, F., \& Gyányi, A. (2007). „Testzsírfóbia”. A modern evészavarok egyike: a testépítő típusú evészavar. Mentálhigiéné és Pszichoszomatika, 8, 203-210.

Túry, F., Sáfrán, Zs., Wildmann, M., \& László, Zs. (1997). Az Evési Zavar Kérdóív (Eating Disorder Inventory) hazai adaptációja. Szenvedélybetegségek, 5, 336-342.

Túry, F., \& Szabó, P. (2000). A táplálkozási magatartás zavarai: az anorexia nervosa és a bulimia nervosa. Budapest: Medicina

Yuan, A.S.V. (2010). Body perceptions, weight control behavior, and changes in adolescents' psychological well-being over time: A longitudinal examination of gender. Journal of Youth and Adolescence, 39, 927-939.

\section{Szerzói munkamegosztás}

Az első szerző a kutatás megtervezésében, koordinálásában, az adatok elemzésében, az eredmények értelmezésében és a tanulmány megszövegezésében vett részt. A tanulmány társszerzői elsősorban az adatfelvételben, az adatok rögzítésében, elemzésében és a következtetések megfogalmazásában múködtek közre.

\section{Nyilatkozat érdekütközésról}

A szerzók ezúton kijelentik, hogy esetükben nem állnak fenn érdekütközések.

\section{FÜGGELÉK}

\section{DAZ program és általános kérdôív}

Kód:

Életkor:

Nem:

Iskolai végzettség:

Kérem, egy 1-5-ig terjedó skálán értékelje az alábbiakat, ahol az 1-es a legrosszabb, a 3-as a közepes, az 5-ös pedig a legjobb jelentésú.

A program kezelhetôsége:

A program külalakja:

A program használata által nyújtott élmény:

A program egyszerúsége: 
A program által formázott figura valósághúsége:

A program által felkínált módosítási lehetóségek mennyisége:

Az Ön általános elégedettsége a programmal kapcsolatban:

Az Ön általános elégedettsége az elkészített alakokkal kapcsolatban (milyen mértékben sikerült kialakítani azt, amit elképzelt):

Válaszait és részvételét köszönjük!

\title{
Studying the applicability of a 3D modelling program, the DAZ Studio on the field of body image measurement
}

\author{
LEINDLER, MILÁN - BENKÓ, ZSÓFIA - LAPIS, FLÓRA - \\ LÉDER, ÁGOTA - MOLNÁR, KARINA - SZALAI, DOROTTYA
}

Background: Examining body image and eating disorders is becoming more and more relevant. The spectrum of symptoms shifts towards body image disturbances, while the occurrence of such diseases increases. Correcting body image is more important than ever since the growing effect of the media contributes to a negative self-evaluation and body image. Body image measures do not keep pace with the achievements of modern science, so many opportunities remain untouched. Goal: The goal of this study is to evaluate the applicability of a 3D modelling program, the DAZ Studio on the field of body image measurement. We aim to verify that the software is capable of measuring the attitude component of body image, the extent and direction of the discrepancy between perceived and ideal body image. Method: Using the DAZ Studio, participants created two figures: first the perceived, actual self, then the ideal, desired self. For the purpose of validation, the Eating Disorder Inventory, the Eysenck Personality Questionnaire, the State-Trait Anxiety Inventory, the Big Five Inventory and the Fallon-Rozin test were used. These tests measured the participants self-evaluation, anxiety, and their attitude towards their body. Results: The population we intend to examine was Hungarian women, our sample consisted of 73 women (average age: 28.3 years, SD: 10.8 years). We found significant correlation between the difference of the two figures and the relevant scales of EDI. We observed a weak correlation $(r=0.272, p=0.02)$ with the drive for thinness scale and a strong correlation $(r=$ $0.521, \mathrm{p}<0.001$ ) with the body dissatisfaction scale on the whole sample. Regarding those under the age of 24, these values were higher $(r=0.454, p=0.03$ and $r=0.639, p<0.001$, respectively). Moreover, we found a connection with the scale measuring bulimia $(r=0.390$, $p=0.013)$ and the one assessing ineffectiveness $(r=0.316, p=0.047)$. No significant association was found with anxiety. Conclusions: The DAZ Studio software can be applied to measure the attitude component of body image. It is able to determine the discrepancy between ideal and perceived body image, which is informative in the diagnostic process. The results show a stronger correlation regarding the younger sub-sample suggesting that the use of the program may be the most effective in identifying eating and body image disorders among adolescent women, who are the most vulnerable for eating disorders.

Keywords: computer-based body image measures, eating disorder, body image disorder, anorexia nervosa, DAZ Studio, body image 